\title{
A New Phase of European Integration: Organised Capitalisms in Post-Ricardian Europe
}

\author{
MARTIN HÖPNER and ARMIN SCHÄFER
}

In the past, economic integration in Europe was largely compatible with the preservation of different national varieties of capitalism. While product market integration intensified competition, member states could build on and foster their respective comparative advantage. Today, this no longer unequivocally holds true. This article contends that a new, 'post-Ricardian' phase of European integration has emerged in which the Commission's and the European Court of Justice's (ECJ's) attempts to promote economic integration systematically challenge the institutions of organised capitalism. It demonstrates this by discussing recent disputes over the Services Directive, the Takeover Directive, and company law. In the current phase of European integration, the Commission's and the ECJ's liberalisation attempts either transform the institutional foundations on which some of the member states' economic systems rely or they create political resistance to an extent that challenges the viability of the European project.

This article starts from two separate but arguably linked observations. First, the aims and strategies of European integration have changed over the last 10-15 years. We will show that supranational actors no longer just eliminate discrimination against foreign companies. Going well beyond merely intensifying competition between national varieties of capitalism, recent directives put forward by the European Commission and decisions of the European Court of Justice (ECJ) aim at transforming national institutions and bringing them in line with the Anglo-Saxon model of capitalism. Market-making no longer implies enforcement of non-discrimination but the abolition of potential institutional impediments to free markets. Hence, we speak of a new, 'post-Ricardian' phase of European integration that threatens the diversity of 'institutional foundations of comparative advantage' (Hall and Soskice 2001). 
Second, the political dynamic of EU integration has changed. In recent years, we have witnessed a hitherto unknown degree of politicisation and, ultimately, a crisis of the European project. In July 2001, the European Parliament voted down a directive that aimed at creating a European market for corporate control by removing national barriers to hostile takeovers. In December 2003, the European Parliament approved a compromise on the Takeover Directive that, according to Internal Market Commissioner Bolkestein, was 'not really worth the paper it was written on'. Between 2004 and 2006, the Commission's Services Directive caused fierce protests, especially in organised economies such as Austria, France and Germany. As with the takeover case, the Commission ended up with a compromise that lagged behind its ambition to effectively liberalise services in the European Union. In both cases, however, case law of the ECJ stepped in and partially adjusted political outcomes to the Commission's initial aims.

What is more, failure and contestation were not limited to individual policy proposals but also affected the Constitutional Treaty of the European Union. In 2005, French and Dutch voters rejected the proposed draft in two referendums. In the French referendum, the voters' 'non' was directly influenced by resistance to the proposed Services Directive. ${ }^{2}$ Many French citizens thought that economic integration had got out of hand. ${ }^{3}$ In June 2008, a majority of Irish voters rejected the 'Lisbon Treaty' - a modified and renamed version of the initial draft. Finally, a number of recent ECJ rulings caused a public outcry in Sweden, Denmark, Germany and Luxembourg in 2007 and 2008. We argue that these developments, at least partially, result from a mode of integration that promotes convergence rather than the coexistence of national models of welfare capitalism.

In this article, we make use of the Varieties of Capitalism (VoC) literature (Streeck 1991; Hall and Soskice 2001) to account for these two observations. In line with this approach, we distinguish two models of capitalism: liberal market economies and organised economies (Höpner 2007). ${ }^{4}$ The latter differ from the former by (a) non-market coordination between firms as well as between firms and their stakeholders; (b) high degrees of public interference in private decisions over finance, investment and consumption; and (c) high degrees of politically mandated redistribution of market outcomes. According to VoC literature, national systems of production and welfare models are composed of a set of institutions that cannot be studied in isolation as they complement each other and are closely interlinked. Hall and Soskice (2001; see especially 17-21) have put such 'institutional complementarities' in the centre of their theory. ${ }^{5}$ Although liberal and organised economies give rise to different production strategies and differ with respect to distributional outcomes, neither type can per se claim superior economic performance.

Analysing European integration from a VoC perspective offers three analytical advantages. First, it provides us with criteria for distinguishing purely technical from transformative change. The case studies in section 
four focus on initiatives with the potential for, from a VoC perspective, nontrivial, 'systemic' change. Since institutional variations of different models of capitalism shape member states' preferences over integration (Firoretos 2001), transformative change is not usually the result of intergovernmental compromises. Second, this perspective cautions against the assumption that economic liberalisation will, in general, improve efficiency. Rather, VoC suggests that gains and losses from liberalisation may be asymmetrically distributed among and inside member states. Hence we take issue with authors who maintain that a lack of input-oriented legitimacy may be counterbalanced by the fact that effective economic liberalisation brings about better outcomes (output-oriented legitimacy). Third, rather than positing a general neoliberal bias of European integration, we can show that market deepening has only recently begun to unsettle the institutional underpinnings of organised capitalism.

This article proceeds as follows. In the next section, we will argue that much of the recent EU literature cast in agency-theoretical terms fails to properly understand the implications of EU liberalisation policies. In section three, we outline why Europe is entering a new phase of integration and how this relates to the strategies of supranational actors. The subsequent fourth section offers case studies on the Services Directive, the Takeover Directive and recent ECJ's rulings on company law. In all of these cases, EU actors did not simply tackle national protectionism, but pushed for convergence of different varieties of capitalism instead. The final section concludes that a political economy perspective contributes to a better understanding of the current crisis in political integration.

\section{The Engines of Liberalisation: The Blind Spot of Delegation Theories}

In this article, we contend that European economic integration has entered a new phase in which it clashes with national varieties of capitalism. Rather than enhancing competition that builds on existing comparative (institutional) advantages, recent Commission initiatives and ECJ rulings propel convergence on liberal capitalism. As these integration attempts affect liberal market economies and organised economies asymmetrically, they stir up conflicts among the member states, as well as between them and supranational actors. Many theoretical accounts of EU politics fail to fully grasp these conflicts. They predominantly aim at explaining the causes and dynamics of integration, while paying less attention to policy consequences. Delegating powers to supranational actors is understood, on the one hand, as the attempt by governments to facilitate cooperation and to enhance credibility or, on the other hand, a way to mitigate collective action problems. Whatever the understanding, European integration is interpreted as a rather technical and therefore apolitical matter, as the search for effective problem-solving techniques. In contrast, a political economy perspective would explain European integration as a deeply political process 
that affects national production and welfare regimes (Hooghe and Marks 1999).

In this section we argue that the currently widely used theoretical vocabulary is amenable to a depoliticised understanding of EU integration. Recently, much of the theoretical literature in this field has been cast in principal-agent language and has made use of the notion of 'delegation'. In general, this literature argues that the main reason for delegating decisionmaking competences to the Commission and the ECJ has been the desire to curtail transaction costs. Negotiations among 27 member states can be timeconsuming and possibly inconclusive if the aim is consensus. Moreover, since member states usually implement EU legislation, there is ample room for opportunistic behaviour and non-compliance. More specifically, Pollack (2003: 21) identifies four functions of delegation: (1) monitoring compliance with the treaty obligations; (2) solving problems with incomplete contracting (interpreting the treaties); (3) expert information; and (4) agenda-setting. Delegation should thus make negotiations more efficient and help to solve collective action problems.

The downside of transferring power to agents is that their preferences may differ from those of the principals, and effective control mechanisms can eat up the potential gains of delegation. Usually agents cumulate expert knowledge, and information asymmetry arises that renders control even more difficult (Kiewiet and McCubbins 1991: 25). In deciding whether to delegate, principals thus weigh the costs of agency drift against efficiency gains (McCubbins et al. 1987: 247). However, principals do not delegate powers only to reduce decision-making costs but also to enhance the credibility of their commitment to certain policy goals. In the first case, controlling the agent is central; in the second, the principals' self-interests need to be kept in check.

Over the last years, both rationales have been incorporated into integration theory. From a neo-functionalist perspective, Burley and Mattli (1993) suggest that the European Court of Justice safeguards member state compliance with prior agreements. As the legal system of the European Union is complex and provides plenty of opportunities to defect, an independent agent is best suited to monitor compliance. However, due to the doctrines of 'direct effect' and 'supremacy' the European Court of Justice has greatly expanded its competences beyond what was initially intended (Weiler 1991; Alter 1998). In this way the ECJ has become one of the 'engines of European integration' (Pollack 2003: ch. 3). These developments have very little to do with a desire to curtail transaction costs. National governments are never fully able to collectively control supranational agents because of shorter time horizons and potential disagreements among them. While delegation necessarily results in gaps of control, member states are often unable to close those gaps (Pierson 1996). There are a number of strategies available for the Commission and the European Court of Justice to circumvent deadlock in the Council and to 
advance integrationist legislation (Héritier 1999; Schmidt 2000). In sum, these arguments rest on the idea that supranational actors propel integration behind the back of national governments that have neither anticipated the accretion of EU competences nor been able to effectively confine them.

The neo-functionalist interpretation of EU politics has not remained unchallenged. Rational institutionalist accounts emphasise that member governments not only know the preferences of the agents but also take the consequences of their actions into account. Member states delegate tasks in order to realise otherwise unattainable benefits of cooperation (Tsebelis and Garrett 2001: 363). Moravcsik's (1998: 36) intergovernmental theory champions the view that international cooperation is an attempt to arrange mutually beneficial policy coordination in the face of the negative external effects of unilateral action. Delegation, in this view, effectively binds parties to negotiation outcomes. In principle, precise rules could credibly commit them, too, but uncertainty about the future makes contracts necessarily incomplete. Since governments cannot specify all possible contingencies in advance, they put supranational actors in charge of monitoring and enforcing their agreements. Hence, Moravcsik stresses credible commitment as the rationale for delegating powers.

More strictly rational-choice approaches point out that member states delegate competences to supranational actors only if there is little conflict between their own views and those of the agent or among the principals themselves. For example, Epstein and O'Halloran (1999: 51) find that the US Congress delegates decisions if informational concerns, i.e. the need for expert knowledge, outweigh distributional issues. Applying the same logic to the EU, Franchino (2004) shows that variation in the Commission's discretion across policy areas depends on the level of policy disagreement in the Council and the complexity of an issue area. The general argument runs that the Council anticipates agency drift and devises ex ante controls such as the comitology procedures or different rules for implementing EU legislation.

Despite their different objectives, approaches that make use of an agencytheoretical vocabulary conceive of delegation as the solution to coordination problems or the need to demonstrate credible commitment. Since supranational actors behave less short-sightedly than governments and are less driven by national interests, delegating decision-making competences enhances the problem-solving effectiveness of the EU; since the Commission is but the 'guardian of the treaty' or a regulatory agency, its autonomy is a warrant for sound decisions; and since the European Court of Justice reinforces compliance with political commitments, its decisions promote the common good. In short, principal-agent literature argues that governments tie their hands in anticipation of welfare gains otherwise unobtainable. Delegation is thus conceived as a positive-sum game.

In this article, we argue that this reading of the principal-agent relationship is incomplete and misses an important aspect of European 
integration because it focuses predominantly on the level of decision-making (national versus supranational) rather than on the policy implications (reregulation versus liberalisation) of delegation. Yet, from a VoC perspective, the consequences of European integration are decisive. Both the Commission and the ECJ do not limit their actions to their initial tasks (which may well be described in terms of credible commitment and transaction cost cutting). We will seek to show that they have instead turned into 'engines of liberalisation' that push for a transformation of national production and welfare regimes. Supranational actors have reinterpreted the Common Market principle of non-discrimination to mean that any institutional difference that potentially hinders economic transactions shall be removed. The case studies will show that this radicalised interpretation of the 'four freedoms' (of goods, capital, services and labour) challenges marketcorrecting policies at the national level and thus limits opportunities for institutionally neutral adaptation. Thus, 'further integration' often means boosting market forces to the detriment of political concerns in the member states. The liberalisation attempts that we subsequently focus on would not have been possible, either as outcomes of political process in the member states or as the results of negotiations between them.

\section{Three Phases of European Economic Integration}

The history of European economic integration can be roughly divided into three phases that differ in their effect on national models of capitalism: a phase of coexistence, a phase of competition and a phase of convergence. ${ }^{6}$ Obviously, these phases overlap and cannot always be neatly separated. Yet the consequences of economic integration for national production regimes allow us to set them apart analytically. During the first phase, between the late 1950s and the mid-1970s, the aspiration was to create a Customs Union, in which tariffs were to be removed and trade between largely autonomous member states was to be facilitated. In these early years, economic integration did not affect the coexistence of national varieties of capitalism. If there were converging trends, they were due to a common process of economic modernisation (Shonfield 1965). EU institutions at that time had the rather limited role of facilitating compromises and making sure that governments lived up to their commitments once they had reached an agreement. The High Authority and the Court were the 'guardians of the treaty' but not vitally important for deepening integration (Moravcsik 1998: ch. 2). At this stage, economic integration was not at odds with domestic policy goals but was seen as a means of achieving them (Milward and Sørensen 1994: 20-21).

The second phase started with the Dassonville (C-8/74, 11 July 1974) and Cassis de Dijon (C-120/78, 20 February 1979) decisions of the European Court of Justice in the 1970s and acquired political clout with the Single European Act and, more specifically, with the introduction of the principle 
of 'mutual recognition' (see Alter and Meunier-Aitsahalia 1994). Under this provision, goods lawfully sold in one member state can also be sold in any other EU country. Mutual recognition is an alternative to either harmonisation or to the host-country principle (Schmidt 2007). In contrast to earlier attempts to create the Common Market, mutual recognition is less dependent on political agreement. Although exemptions are possible, the country-of-origin principle leads to an abdication of national sovereignty. Member states are no longer exclusively in a position to determine which products can be marketed domestically. Another feature of the competition phase of economic integration was that European actors were no longer sidelined but, rather, took centre stage. Making skilful use of legal and political authority to expand their own competences, they became the 'engines of integration' (Pollack 2003). However, their room for manoeuvre was unevenly distributed.

European integration has been characterised by the asymmetry between 'negative' (market-enforcing) and 'positive' (market-regulating) integration (Scharpf 1996; 1999: 43-84). Yet, the discrepancy between negative and positive integration is, in principle, compatible with the existence of different varieties of capitalism. Product market liberalisation increases competition between firms from different countries. As long as different institutional settings are associated with different comparative advantages (Franzese 2002: 184-190), transformative pressure on supply-side institutions does not necessarily occur. In fact, as the VoC literature argues, competition may reinforce differences between countries (or regions). The reason is that firms make use of open borders to shift their activities to production locations that offer the best institutional support - for example, with respect to the availability of particular skill compositions of employees, flexible or stable employment patterns, etc. Hall and Soskice (2001: 57) have called this 'institutional arbitrage'. In this respect, market integration can stabilise institutional differences between European varieties of capitalism. We conclude that competition between national varieties of capitalism intensified during the second phase of European integration. But, in the end, the Ricardian logic of comparative advantages ${ }^{7}$ determined Europe's impact on stability and change of national production regimes.

This logic no longer seems to hold, although, from a purely technical point of view, the Commission and the ECJ simply apply the logics of nonrestriction (rather than non-discrimination) and of mutual recognition, which are well known from the second phase, to other fundamental freedoms (the freedom of establishment, free capital markets and free rendering of services). The consequences, however, differ. After having largely completed product market integration, liberalisation now directly affects domestic institutions of organised capitalism. In this third, "postRicardian' phase, Commission initiatives no longer create a level playing field among EU countries or simply strive for unhindered competition between national welfare and production models. Instead, the Commission 
promotes the modernisation of European economies along the lines of the Anglo-Saxon model. Hence, while European integration has always been geared towards market-making, it has only recently begun to destabilise national varieties of capitalism, leaving the Ricardian logic of diversity and comparative advantages behind. At present, both the Commission and the ECJ's rulings create pressure for institutional convergence.

This might seem surprising, given that a majority of Commission staff is sympathetic to the project of 'regulated capitalism' (Hooghe 1999: 360). However, we do not postulate that Commissioners and ECJ judges are unabashed neoliberals. From their point of view, the 'post-Ricardian' integration phase may simply be a coherent, logically consistent application of successful integration features to new areas (non-discrimination, mutual recognition), irrespective of disruptive consequences for rule-takers. To lend credibility to our argument, we only need to assume that (1) European actors aim at deepening integration and that (2) they give higher priority to this goal than to the preservation of national autonomy (the protection of institutional differences, in other words, has no intrinsic value).

Of course, EU decisions sometimes had a transformative impact on national economies in the past, too, mainly during the second phase. For example, the European Commission and the ECJ regularly used EU competition policy to push for economic liberalisation whenever they were able to decide without the agreement of the Council of Ministers (Scharpf 2006: 853; Thatcher 2007: 157). EU actors used their competences to redefine which economic activities were of public interest and, therefore, exempt from Common Market requirements. The difference to the third phase of European integration is, however, that these interventions still went under the heading of 'non-discrimination'. The goal was to eliminate a disguised protectionism on the part of the member countries and, as a consequence, to allow for fair competition between companies of different origin. Lately, the Commission's understanding of a level playing field has changed to mean that institutional differences as such impede competition. ${ }^{8}$ Liberal market economies and organised economies are no longer equally valid production regimes; rather, the institutions of the latter are seen as barriers to full economic union. In promoting further liberalisation, EU actors are able to resort to practices - such as the country-of-origin principle - that were introduced during the second phase and successfully established in product market liberalisation.

Our case studies demonstrate that recent integration initiatives aimed at liberalising organised economies, ultimately pushing them towards the Anglo-Saxon model. The Commission's initial draft of the Services Directive applied the country-of-origin principle to cross-border services. This meant that the host country would have forfeited capacity to regulate economic action on its own territory. While the political process substantially modified this proposal, consecutive ECJ decisions have largely compensated for this political failure (first case study). With the Takeover 
Directive the Commission wanted to establish a Europe-wide market for hostile takeovers, and once again, at least partially, the ECJ took over initiative after the Commission failed (second case study). A number of recent ECJ decisions effectively prevent national governments from subjecting firms to the regulations of national company law, even if these firms do business nowhere else but in that country (third case study). All our cases can be understood as the attempt to push national forms of capitalism in more market-driven directions by denying national democratic institutions access to economic regulation. ${ }^{9}$ Arguably, this puts the legitimacy of EU politics in question and might foster opposition to European integration in the member states.

\section{The Quest for Liberalisation: Three Case Studies}

\section{The Services Directive}

This first case study demonstrates how both the Commission and the Court push liberalisation further than the member states explicitly requested in the treaties. In fact, the Commission's proposed Services Directive would have deprived national governments of the ability to regulate certain forms of domestic economic action. Not surprisingly, it led to the most farreaching clash between the Commission and the public in several member states to date and contributed to the current crisis of integration. What is more, this case study also shows that the European Court of Justice was able to partially reverse the political failure of the Commission's initial proposal.

The aim to integrate European services markets is part of the Internal Market programme and the Lisbon Strategy in particular (European Commission 2005). Naturally, services markets are harder to integrate than product markets. While products can be exported, services are attached to the persons who deliver them. Therefore they only take place when supply and demand come together at the same location. In Article 50 of the Treaty establishing the European Communities (TEC), ${ }^{10}$ member states express agreement upon the principle that service suppliers from other member states must not be juristically discriminated against. Article 50 states:

Without prejudice to the provisions of the Chapter relating to the right of establishment, the person providing a service may, in order to do so, temporarily pursue his activity in the State where the service is provided, under the same conditions as are imposed by that State on its own nationals. (Emphasis added)

In contrast, the first two paragraphs of Article 16 of the Services Directive state: 
(1) Member States shall ensure that providers are subject only to the national provisions of their Member State of origin which fall within the coordinated field. Paragraph 1 shall cover national provisions relating to access to and the exercise of a service activity, in particular those requirements governing the behaviour of the provider, the quality or content of the service, advertising, contracts and the provider's liability.

(2) The Member State of origin shall be responsible for supervising the provider and the services provided by him, including services provided by him in another Member State. (Directive Com(2004)0002; emphasis added)

Apparently, the Commission wanted to weaken governments' control over posted workers in order to accelerate the completion of the Internal Market. Whereas the wording of the treaty implies that suppliers have to rely on the regulations of the state in which the services take place, the Commission put forward the country-of-origin principle. ${ }^{11}$ This principle resembles the method of 'mutual recognition', which the European Court of Justice established with the Cassis de Dijon decision and which was subsequently applied to product market integration in general. However, the country-of-origin principle has more far-reaching consequences than mutual recognition since the host country has not only to accept the regulatory standards of another member state but also to trust foreign authorities to enforce those standards on posted workers. In the case of letterbox companies, the host country's loss of control is particularly severe. In this case a company can incorporate in another member state to avoid national regulations without doing business anywhere else but in its home country. In both cases the host country's ability to enforce regulatory standards is virtually absent.

Given the potential consequences of the directive, it is hardly surprising that it sparked off protests, especially in highly regulated countries such as Austria, Belgium, France, Germany and Sweden. The longer the discussion lasted, the more unrealistic became an adoption of the country-of-origin principle. However, Internal Market Commissioner McCreevy (the successor to Bolkestein, who had initiated the directive) refused to withdraw the proposed directive although he knew it was politically non-enforceable. ${ }^{12}$ Protests against the Services Directive were exceptionally prominent in France, and in the very context of this discussion the French public rejected the Constitutional Treaty in the May 2005 referendum.

Subsequently, the directive was watered down in two steps. First, in November 2005, the European Parliament's Internal Market Committee proposed a version in which it maintained the country-of-origin principle but explicitly excluded several areas such as labour law and social protection. Second, in February 2006, an EP majority went beyond the 
suggestions of the Internal Market Committee and proposed a version in which the country-of-origin principle was abolished: $394 \mathrm{EP}$ members voted for the proposal, and $215 \mathrm{EP}$ members voted against it. Comparable to the Takeover Directive, a combination of a left-right divide and a "clash of capitalisms' occurred. Although the adopted proposal relied on a compromise between the Socialist and the conservative EPP factions, majorities of conservative MEPs (in addition to some others) from Great Britain, Spain, Poland, Hungary, the Czech Republic and the Netherlands favoured more liberalisation - though not necessarily in the radical manner initially proposed by the Commission - and voted against the proposal.

In April 2006, the Commission presented a revised directive that included the changes that Parliament had asked for. Resistance to the directive was not strong enough in the Council to establish a blocking majority (which the Commission might have suspected - though this is speculation). In May 2006, the economics ministers subscribed to a 'joint position' based on the revised version of the directive. The European Parliament also accepted this version with only minor modifications in November 2006, and the Council of Ministers finally approved the Services Directive in December (2006/123/ $\mathrm{EC})$. One of the consequences of the directive is that member states have to document and justify any restrictions they impose on foreign suppliers to maintain the public interest, such as the protection of workers, public health, the protection of the environment or the protection of consumers.

In sum, the Commission's initial proposal for the Services Directive including the country-of-origin principle - was substantially modified during the political process. Subsequently, however, the ECJ decision on Laval (C341/05, 18 December 2007) partly reversed the political compromise. The Court decided in Laval that industrial action directed at bringing about equal pay for domestic and posted workers in the host country might conflict with free rendering of services. Among other controversial aspects, the ECJ decision comprised a somewhat surprising interpretation of the 1996 Posted Workers Directive (96/71/EC) which, according to the Court, aimed at defining the maximum regulation governments - and trade unions were allowed to impose on posted workers and their firms. Through this reinterpretation, the ruling effectively restored the country-of-origin principle for all regulations that go beyond those explicitly mentioned in Article 1 (3) of the Posted Worker Directive (for a discussion of Laval see Joerges and Rödl 2009). In Sweden, the Laval case prompted protests on a scale only comparable with the protests against the Commission's initial proposal for the Services Directive. The other case studies will follow up on the ECJ's ability to liberalise through adjudication.

\section{The Takeover Directive}

The Takeover Directive (2004/25/EC) demonstrates how the Commission strategically used its power as master of the 'rules of the game'. In order to 
find majorities for liberalisation measures that superseded national preferences, the Commission sought to bribe several member states from opposing liberalisation. For this purpose, it set agendas that asymmetrically hurt the member states. Contrary to its rhetoric, the Commission tried to achieve liberalisation by avoiding the so-called 'level playing field'. This strategy runs parallel to what Schmidt (2000: 46-50) has called the 'divide and conquer' strategy. ${ }^{13}$ This case study underlines that the Commission is a political actor rather than a broker between national interests and that - as in the case of the Services Directive the ECJ has the potential to compensate for the Commission's political failures.

From a comparative political economy perspective, takeover regulation is a key characteristic of production regimes as it governs shareholders' rights and defensive measures in the event of takeover bids. In liberal market economies, takeover regulation aims at activating markets for corporate control in order to force managers to act in a shareholderoriented way. In contrast, organised economies are characterised by stakeholder-oriented corporate governance. Managers are supervised by company networks, creditors, insiders and large shareholders rather than takeover markets. The absence of hostile takeovers, in other words, is a characteristic feature of the 'Rhenish' form of capitalism (Albert 1993). The emergence of markets for corporate control could help unravel this form of capitalism and bring about liberal capitalism (Höpner and Jackson 2006).

Member states have obliged the Commission to promote a free European capital market. The first paragraph of Article 56, TEC states that 'all restrictions on the movement of capital between Member States and between Member States and third countries shall be prohibited'. Investors shall be free to invest anywhere in Europe and not be discriminated against. However, the principle of non-discrimination is not the same thing as a ban on restrictions to hostile takeovers. The member states have neither agreed on harmonising takeover regulation in order to actively promote hostile takeovers nor consented - which is the logical consequence - to providing shareholders with primacy over stakeholders. Internal Market Commissioner Frits Bolkestein, however, made no secret of the fact that exactly this was intended by the Takeover Directive: 'If Europe really wants to become the most competitive and most modern economic area, it must leave the comfortable setting of the Rhenish model and subject itself to the harsher conditions of the AngloSaxon form of capitalism. ${ }^{14}$

The Commission had already presented a first draft of the Takeover Directive in 1989. It was changed several times until, in June 2001, the European Parliament voted down a (still relatively strict, market-enforcing) conciliation compromise by the narrowest possible margin: $273 \mathrm{EP}$ members voted for the proposed directive, 273 voted against, and 22 abstained. The 
proposed directive aimed at strictly implementing the so-called neutrality rule, i.e. obliging managements not to initiate any defensive measures against hostile takeovers unless the shareholders' meeting explicitly authorised the management board to do so. Hix et al. (2007: 215) call the Takeover Directive 'one of the most high profile pieces of legislation ever to pass through the European parliament'. The battle over the Takeover Directive witnessed an amount of politicisation that had, until then, been unknown.

The European Parliament's vote has been analysed in several articles (Callaghan and Höpner 2005; Ringe 2005; Hix et al. 2007: chapter 11). While a left-right divide occurred among the small parties, members of the large conservative and social democratic EP factions voted with respect to their national origin (in a 'clash of capitalisms' constellation). The less shareholder-oriented national corporate governance regimes were, the more likely it was that both factions uniformly opposed the proposed directive. Conversely, when the corporate governance system of a country was shareholder-oriented, social democratic EP members joined their conservative counterparts in support of the directive.

In order to find ways out of its blocked liberalisation attempt, the Commission appointed a High-Level Group of Company Law Experts, led by Jaap Winter, which presented its report in January 2002. The main problem was the relationship between takeover law and other areas of national company law: as long as most member states allowed companies to introduce several forms of unequal voting rights, de facto defensive measures against hostile takeovers exceeded those measures the Takeover Directive intended to remove. The Winter group suggested temporarily abandoning all forms of unequal voting rights during takeover contests. Yet the revised directive proposal which the Commission decided to adopt in October 2002 differed from the Winter report in an important manner. Besides introducing the strict neutrality rule, it aimed at inhibiting all regulations that restrict the voting rights of single shareholders to defined amounts (such as 20 per cent of the overall vote as in the VW case, for example). In contrast, the proposed directive did not affect multiple voting rights. ${ }^{15}$ In effect, the Commission refrained from 'one share, one vote' as the guiding principle for takeover battles.

The Commission frankly stated the rationale underlying the revised blueprint. 'The Internal Market Commissioner perceives it as important to secure majorities for his projects', explained Bolkestein's speaker Jonathan Todd. ${ }^{16}$ Germany had already abolished unequal voting rights with its 1998 Corporate Sector Supervision and Transparency Act. ${ }^{17}$ In contrast, multiple voting rights - widespread especially in Sweden and France, but also present in countries like Belgium, Great Britain, Finland and Denmark - were permitted to remain intact. Even though the Commission lacked a majority for full liberalisation, it still hoped to prevent member countries from joining Germany in its opposition to the Takeover Directive. ${ }^{18}$ 
Liberalisation, in other words, only seemed achievable by not constructing a level playing field. In 2002, Commissioner Bolkestein announced that multiple voting rights could not impede takeovers and that the Commission might address multiple voting rights at a later time if they turned out to be systematically used to hamper takeovers. ${ }^{19}$

In February 2003, the Greek Council Presidency tried to find a compromise between the Winter report and the Commission's proposal that also targeted the Scandinavian-style system of multiple voting rights. Yet the French double voting rights system remained untouched. This caused fierce resistance from Sweden, Finland and Denmark, in which the Wallenberg group especially - by far the most important family-owned investor group in Sweden - figured prominently. France insisted that its model of double voting rights did not cause any restrictions to hostile takeovers. In contrast, the German government insisted that a fair solution would also have to forbid French double voting rights, thereby being quite aware of the fact that, if it succeeded, the outcome would be a blocking minority with France and the Scandinavian countries at its core. More and more, member countries began to agree upon a non-transformative solution. As a consequence, the Commission's strategy to split the member states ran aground. In October 2003, Commissioner Bolkestein announced his intention not to support a solution 'without any value added to the current situation'. ${ }^{20}$ The Commission's veto implied the necessity for unanimity among the member states, i.e. resistance of a single country could have prevented a Council compromise. Yet, in the end, the Commission achieved the opposite of what it had intended: rather than having isolated Germany, it stood alone in the face of a united front against its liberalisation plans. The European Parliament also accepted the Council compromise in December 2003. From the Commission's point of view, national protectionism had gained the upper hand and harmed the progress of European integration.

The history of the European Takeover Directive, however, does not end with the political compromise. From 2002 on, a series of ECJ rulings against special voting rights for public authorities, known as 'Golden Shares', set in. ${ }^{21}$ With its decisions against the UK and against Germany in particular (C-112/05, 23 October 2007), the ECJ began to ban special voting rights that were non-discriminatory (because they applied to all shareholders irrespective of their national origin) and that were put down in company statutes rather than national laws. ${ }^{22}$ Moreover, since the ECJ has abandoned the initial aim to remove restrictions 'on the movement of capital between Member States' (Article 56, TEC) and concentrates instead on restrictions of free investment in general, virtually any element of national company and takeover law may now be tackled judicially - including, in principle, employees' supervisory board codetermination. In fact, the decisions on Centros, Überseering, and Inspire Art, to which we now turn, already follow this logic. 


\section{Company Law and the European Court of Justice}

Our third example demonstrates that the European Court of Justice is an independent force of European liberalisation. Though the practical effects of its judgments on the member states' capacity to monitor and regulate their economies do not lag behind those of the Commission, the Court's rulings are widely seen as technical, rather than political matters (Burley and Mattli 1993: 44). And while the Court was not affected by the wave of politicisation of European affairs that occurred after Maastricht, over the last couple of years this has changed. In 2007 and 2008, the decisions on Viking (C-438/05, 11 December 2007), Laval (C-341/05, 18 December 2007) and Rüffert (C-346/06, 3 April 2008) attracted considerable public attention. ${ }^{23}$ In this section, we focus on a series of company law decisions that established that the so-called 'seat-of-management principle' violates European law. The consequence is a de-institutionalisation comparable to the liberalisation attempt witnessed in the first case study: national governments lose the ability to regulate domestic economic transactions.

In the past, the German Federal Court of Justice - just like the courts of Austria, Belgium, France, Luxemburg, Portugal and Spain - judged in line with the seat-of-management (or seat-of-administration) rule. This principle implies that the company law of the nation in which a firm is domiciled, rather than the law of the nation in which it was established, must be applied to the firm. In other words, if a firm's administrative seat was in Austria, it could only retain corporate status if it was incorporated in accordance with Austrian law. In fact, the defence of national rules of incorporation (especially with regard to employee representation and taxation) was the main reason why an agreement on the European Company Statute was difficult to achieve. Although it created some loopholes, the final political compromise was meant to preserve diversity (Fioretos 2008). However, while it took four decades to craft a political compromise, four years were sufficient for the European Court of Justice to unsettle it. The decisions on Centros, Überseering and Inspire Art, in 1999, 2002 and 2003 respectively, stipulate that the seat-of-management principle is inconsistent with the freedom of establishment, even if so-called 'letterbox firms' (companies that incorporate in one country to eschew the company law of the country where they do business) are involved. In this case, too, liberalisation has been promoted by a generous - some might say, unwarranted - interpretation of the 'four freedoms'. The Treaty of the European Communities guarantees, for instance, the freedom of establishment:

Restrictions on the freedom of establishment of nationals of a Member State in the territory of another Member State shall be prohibited. Such prohibition shall also apply to restrictions on the setting-up of agencies, branches or subsidiaries by nationals of any Member State established in the territory of any Member State. (Article 43, TEC) 
Until 1999, few would have insisted that the treaty guaranteed the right to freely choose among national company laws regardless of physical location since Article 48 explicitly adds:

Companies or firms formed in accordance with the law of a Member State and having their registered office, central administration or principal place of business within the Community shall, for the purposes of this Chapter, be treated in the same way as natural persons who are nationals of Member States.

The Centros decision raised doubts about the seat-of-management rule without clearly replacing it. Centros Ltd., a wine company, was established by two Danes under British law. In terms of its business, however, the firm was exclusively engaged in Denmark. The incorporators announced that the only reason for the foreign incorporation was to avoid the minimum capitalisation requirement for Danish companies. The Danish commercial registry argued that this approach was an unlawful circumvention of Danish minimum requirements and therefore refused to register the company's branch office. A national court asked the ECJ for a preliminary decision. In its statement to the Court, the Commission argued that the complainants were right and that the Danish state was not allowed to apply its own standards on Centros. The Court decided in favour of the company and Commission position (C-212/97, 9 March 1999).

The Court argued that the use of foreign letterbox companies explicitly to circumvent Danish minimum requirements was a legitimate measure that must not be objected to by the state the firm operates in:

[T] he fact that a national of a Member State who wishes to set up a company chooses to form it in the Member State whose rules of company law seem to him the least restrictive and to set up branches in other Member States cannot, in itself, constitute an abuse of the right of establishment. ... [T] he fact that a company does not conduct any business in the Member State in which it has its registered office and pursues its activities only in the Member State where its branch is established is not sufficient to prove the existence of abuse or fraudulent conduct which would entitle the latter Member State to deny that company the benefit of the provisions of Community law relating to the right of establishment. (Marginal numbers 27 and 29)

In what followed, lawyers discussed controversially whether the Court had generally forbidden member states to apply the seat-of-management rule. It was the German Federal Court of Justice that called for a leading decision. In the case then at hand, Überseering BV, a Dutch construction firm, employed a German contractor, a limited liability company $(\mathrm{GmbH})$. 
The BV sued the GmbH for damages by reason of alleged defects in the work performed. Just prior to the filing of suit, however, the BV was purchased by two Germans, who then managed the BV from Germany. The lower German courts dismissed the BV's complaints against the German contractor as long as the owners refused to form a $\mathrm{GmbH}$ out of the $\mathrm{BV}$; in its current form, the German court argued, the BV had no legal capacity in Germany. In its decision, the European Court - in accordance with the Commission's statement on the case - judged that the BV was right (C-208/00, 5 November 2002). With this decision, the seat-of-management rule was toppled. But Überseering was not a letterbox firm in the classical sense.

A third decision combined the generality of the Überseering decision with a Centros-style circumvention matter. A Dutchman established Inspire Art Ltd. under British law and requested the registration of the company's Dutch branch office. The Dutch registry refused and argued that specific Dutch minimum rules for foreign companies - above all, a certain minimum capitalisation - applied. Again, the European Court sided with the company and with the Commission (C-167/01, 30 September 2003). The Dutch state, the Court argued, was not allowed to impose its corporate law minimum standards on Inspire Art although it operated nowhere else than in the Netherlands.

These juridical innovations have far-reaching consequences (Gelter 2005; Siems 2002). They imply an effective deregulation of European company laws. Most notably, this deregulation applies to situations in which, from the perspective of the member states, no foreigners are involved. As in other cases, the Court transformed the principle of non-discrimination into a ban on restrictions on the four freedoms. Differences in national company law as such are now seen as restrictions on the freedom of establishment. The decisions on Centros, Überseering and Inspire Art effectively hollow out national company law. The decisions actually apply the American situation to Europe: in the US, most firms are founded in the state of Delaware because of its lax requirements (Roe 2005). ${ }^{24}$ Whoever dislikes national company law is now free to pick one of the other members' company laws. As a consequence, the decisions put company laws, not production locations, into direct competition with each other and impose pressure to deregulate. Tony Blair announced the intention to let the British Ltd. become the European Delaware firm. ${ }^{25}$ In fact, the ECJ decisions have caused a boom of Ltd.-type foundations in European countries. In Germany, for example, the website www.go-limited.de offers a complete package for the establishment of a British 'Limited Liability Company' for only $€ 260$. The advertising firm - which is of course not the only supplier claims to have already founded around 38,000 Ltds. in Germany (January 2010).

Until today, the most controversial - and, from a VoC viewpoint, most relevant - matter has not been juristically clarified: the impact of the Court's 
decisions on supervisory board codetermination in countries such as Germany (Dammann 2003). The current situation is that no supervisory board codetermination would be applied to a British Ltd. operating exclusively in Germany that grows beyond 500 employees. In its statement on the Centros case, the German government argued that, regardless of other reasons, the seat-of-management principle was necessary in order to secure appliance of employees' codetermination rights (see marginal numbers 87-89 of the Centros decision). The European Court did not uphold this objection. However, in the Überseering decision, the Court declared cautiously:

It is not inconceivable that overriding requirements relating to the general interest, such as the protection of the interests of creditors, minority shareholders, employees and even the taxation authorities, may, in certain circumstances and subject to certain conditions, justify restrictions on freedom of establishment. (Paragraph 92)

Thus far, experts have discussed controversially whether this may authorise the German state to impose supervisory board codetermination on firms whose legal form is based on foreign company law that operate in Germany.

As a matter of fact, ECJ case law is not the only development related to European integration that could undermine codetermination. The European Company Statute (2001/86/EC) and the Merger Directive (2005/19/EC), too, create loopholes to circumvent codetermination. Of course, legal possibilities do not necessarily imply that actors choose them. So far, German companies with foreign legal forms rarely have more than 500 employees. ${ }^{26}$ However, our benchmark is a situation in which the state could govern the codetermination behaviour of the companies inside its national territory. European liberalisation has led to a situation in which this ability is diminishing. The realistic scenario is certainly not that companies will escape from supervisory board codetermination as soon as they legally can. Rather, we anticipate a smooth but ongoing evolution of heterogeneity of codetermination practices in Germany that will put pressure on the government to generally cut back codetermination rights.

\section{Conclusion: Legitimacy Problems in Post-Ricardian Europe}

After having largely completed the Internal Market for products, European economic integration has entered a post-Ricardian phase. Attempts to liberalise services, takeover practices and company law differ in their potential consequences from product market integration. Originally, the removal of trade barriers and de facto discriminatory practices intensified competition between national production and welfare regimes. This competition did not exert transformative pressure on national labour law, industrial relations, company law, takeover regulation or supervisory board 
codetermination as long as firms in highly regulated or organised economies remained economically successful. In the current phase of European integration this no longer holds true. Now, in order to deepen European integration, the Court and the Commission apply the principles of mutual recognition and of non-restriction to services, capital markets and free establishment. They thereby directly affect member states' institutions and push them towards the Anglo-Saxon model of capitalism. In a postRicardian setting, the Commission and the European Court of Justice interpret institutional differences as such as restrictions on the four freedoms. Thus, national institutions that make up different varieties of capitalism become the target of political and juridical interventions. Although non-discrimination and mutual recognition are well-known principles of European law, their application to new problems is having a very different impact on both institutional transformation and legitimacy. The current transformation of European integration, thus, is a prime example for what Streeck and Thelen (2005) call 'institutional conversion': settings can change when traditional principles are applied to achieve new goals.

Not surprisingly, the push for convergence has met with resistance in many member states. We contend that the current crisis of European integration - a series of failed directives, protests against Commission initiatives and ECJ decisions and the vote against the Constitutional Treaty and the Lisbon Treaty in France, the Netherlands and Ireland - has to be understood, at least in part, as a reaction to the EU interfering with national production and welfare regimes. Of course, opposition to the EU takes different forms in different countries. Many French voters feared social cuts, whereas Irish opponents to the Lisbon Treaty were afraid of higher taxes. In each case, however, the voters defended the right to nationally determine core elements of economic and social policy. Accordingly, the current wave of politicisation of EU affairs and European integration in general are inconsistent with a purely technical understanding of delegation. Relying on principal-agent theory, much of the recent literature has focused on the efficiency gains of delegating powers. Autonomous decisions of non-elected actors are frequently welcomed because they are meant to creatively 'fill in gaps in the legal framework' and 'ensure the achievement of the Treaties' objectives notwithstanding legislative inertia on the part of the Council' (Arnull 2003: 180). Frequently, the literature on the Commission and the ECJ assumes that activist behaviour on the part of European agents is normatively desirable because it produces better results than political negotiations (Pollack 2003: 408). The case studies in this article support a different interpretation. In none of the cases was the dominant motive cutting transaction costs or ensuring credible commitments so as to realise Pareto improvements.

We have argued that current Commission initiatives and ECJ case law drive production regime institutions in the direction of Anglo-Saxon-style 
market capitalism. It may be argued that other initiatives exist pushing in the opposite direction, thereby counterbalancing liberalisation. However, we did not choose our cases randomly but have dealt with the ones that are most salient from a VoC perspective. Is the 1994 Directive on European Works Councils $(94 / 45 / \mathrm{EC})$ a counterexample? We think that the institutional change that the EWC Directive brought about must not be confused with institutional change imposed upon domestic production regime regulation. European Works Councils are interlinks between national industrial-relations institutions, leaving the institutions themselves intact rather than replacing them. In contrast, recent ECJ decisions on company law (our third case study) transform member states' capacity to govern the codetermination behaviour of domestic firms.

Liberalisation from above raises doubts about the democratic legitimacy of European politics, especially if supranational actors' strategies are in conflict with the wording and the initial meaning of the Treaties. From a political science perspective, the crucial question is whether member countries, the 'principals', are still in control of the integration process. Based on the analysis in this article, we would tend to answer in the negative. Hence we deviate from insights brought about by intergovernementalists such as Moravcsik, who insists that European liberalisation is both in line with the preferences and under control of the member states. While this might have been true in the past, it no longer seems to capture the dynamic of European integration in the post-Ricardian phase. We conclude that questions of legitimation have to be posed anew. If delegation neither simply improves the efficiency of EU policy-making nor produces Pareto optimal outcomes, output-oriented legitimacy cannot make up for the lack of input-oriented legitimacy.

However, one might object, it is so obvious that the member states are deadlocked with immobility and overregulation that the "neo-liberal bias of the EU, if it exists, is justified by the social welfarist bias of current national policies' (Moravcsik 2002: 618). Since liberalisation improves the economic performance of EU states, a legitimacy deficit is the lesser evil in comparison to stagnation. Yet, a varieties-of-capitalism perspective casts doubts on the premises of this argument. The impact of EU legislation may differ across (as well as inside) member states (Fioretos 2001; Menz 2005). Some states may benefit from deregulation. For others, however, liberalisation may result in a decomposition of the institutional logic their production regimes rely on. If this happens, output-oriented arguments cannot be maintained and Europe will indeed face a democratic deficit.

We have suggested that the liberalisation attempts of the post-Ricardian phase are either successful or they bring about crises of integration. Failed referendums on the Constitutional Treaty and considerable Euro-scepticism throughout the Union indicate that the 'permissive consensus' of European integration is dissolving. 'Integration by stealth' (Majone 2005) has reached its limit because European decisions are in conflict with national welfare 
traditions or, as we have shown, with European varieties of capitalism. We conclude that the legitimacy requirements of mutual recognition and non-restriction differ according to the problems they are applied to. For the first time, European economic integration faces substantial public protest. It remains to be seen whether public opposition will motivate the ECJ and the Commission to refrain from pushing for further liberalisation. Even though Alter (2001: ch. 5) argues that the ECJ is a cautious and politically responsive actor, setbacks encountered in the ratification of the Constitutional Treaty did not deter the Court in the Laval, Viking and Rüffert cases. The same applies to the Commission. Paradoxically, the appropriate answer to the recent crises seems to be to intensify economic integration. After the French and Dutch rejection of the Constitutional Treaty, Internal Market Commissioner McCreevy refused to take the proposed Services Directive off the table, and Commission President Barroso announced that the Commission would 'of course ${ }^{, 27}$ push ahead with its reform programme. The reactions to the Irish referendum were of the same tenor. They show an alarming tendency of European elites not to take the growing unease of the public seriously enough. This unease may, however, undermine public support for European integration in general.

\section{Acknowledgements}

We would like to thank Helen Callaghan, Liesbet Hooghe, Nicolas Jabko, Fritz W. Scharpf, Susanne K. Schmidt, Tobias Schulze-Cleven, Christa van Wijnbergen and two anonymous reviewers for extremely helpful comments.

\section{Notes}

1. Financial Times, 18 October 2004, p. 6.

2. See, for example, Financial Times, 20 April 2005, p. 6; Financial Times, 30 May 2005, p. 6; and Maatsch (2007) for a comprehensive analysis.

3. For more details, see European Commission (2005).

4. Of course, it might be oversimplified to talk about just two types of capitalism. V. Schmidt (2002), in contrast, distinguishes three variants, Amable (2003) even five. In an extended discussion, one could analyse the effect of European integration on these various national models. Yet, we still maintain that the VoC approach offers a valuable analytical starting point to show how the impact of European integration on the member states differs (1) over time and (2) across varieties of capitalism.

5. See the debate on institutional complementarity in issue 2, 2005 of Socio-Economic Review.

6. Cf. Balassa (1961) for a theoretical account of different stages of economic integration.

7. David Ricardo (1772-1832) initially developed the theory of comparative advantages, which maintains that free trade creates wealth for all parties involved if they focus on goods with a relative cost advantage. The $\mathrm{VoC}$ literature discusses how different sets of institutions of national economies (in spheres such as industrial relations, corporate 
governance and skill formation) create comparative advantages. Note that the economic literature to date often speaks of 'competitive advantages' (Porter 1990).

8. Hence, our argument differs from accounts that posit a general neoliberal bias of European integration, either due to structural reasons (Scharpf 1996) or due to pressure from influential interest groups such as the European Roundtable of Industrialists (van Apeldoorn 2000). While European integration has been promoting increased competition for decades, the extent of its interference has grown so substantially in the post-Ricardian phase that it endangers the viability of different models of capitalism.

9. We define institutions as a legitimised and enforceable set of rules which enable societies to govern its members' (in our case, economic) actions. Hence, we deviate from a rational choice understanding of institutions as strategic equilibriums. We are concerned with the capability of the member states to regulate economic activities on their own territory.

10. In this article, all cited paragraphs of the Treaty of the European Communities refer to the numbering introduced after the Amsterdam Treaty of 1997.

11. In fact, the ECJ had already begun to apply the country-of-origin principle to services before the Services Directive was negotiated. In the Finalarte case, the ECJ reasoned that 'the application of the host Member State's national rules to providers of services is liable to prohibit, impede or render less attractive the provision of services to the extent that it involves expense and additional administrative and economic burdens' (C-49/98, 25 October 2001, §30).

12. Tageszeitung, 4 March 2005, p. 2.

13. Schmidt uses the term 'divide and conquer' to describe the Commission's strategic use of infringement procedures in order to change member states' preferences on liberalisation measures. In both cases, the Commission tries to play opposing member states off against each other by manipulating their pre-strategic interests. We thank Susanne Schmidt for her suggestion that in both cases, in principle, the Commission's strategy would be unsuccessful if the member states opposing liberalisation committed themselves to 'solidaristic' behaviour.

14. Neue Zürcher Zeitung, 9 November 2002, p. 83 (our translation).

15. Multiple voting rights imply, for example, that the shares of certain shareholders are weighted twice as high as those of others.

16. Financial Times Deutschland, 4 October 2002, p. 29 (our translation).

17. Gesetz zur Kontrolle und Transparenz im Unternehmensbereich (KonTraG).

18. Protest against the asymmetric proposal also occurred inside the Commission; see Financial Times Deutschland, 25 September 2002, p. 14.

19. See Börsen-Zeitung, 22 June 2002, p. 6.

20. Börsen-Zeitung, 14 October 2003, p.7 (our translation).

21. The first cases were C-483/99 (Commission/France, 4 June 2002), C-503/99 (Commission/ Belgium, 4 June 2002) and C-98/01 (Commission/United Kingdom, 13 May 2003).

22. Compare Zumbansen and Saam (2007) regarding the broader implications of the Volkswagen decision.

23. In all of these cases, the ECJ decided that national regulations constituted undue restrictions on free movement although they were not discriminating against foreigners - in line with the ECJ's general move from non-discrimination against foreigners to nonrestriction of economic action.

24. Note that the potential effects are much more serious than the well-known US-style Delaware effect: Unlike the US, Europe consists of quite different varieties of capitalism. In the US, the Delaware effect enables firms to avoid, for example, minimum capitalisation standards. In Europe, however, the Centros, Überseering, and Inspire Art decisions offer an exit out of codetermination, which - in our view - is one of the main pillars of a historical class compromise.

25. See Börsen-Zeitung, 15 September 2004, p. 2.

26. However, the number of German companies with more than 500 employees whose legal form is based on foreign company law grew from 17 at the end of 2006 to 29 at the end of 
2008. See data provided by the Hans Böckler Foundation: http://www.boeckler.de/pdf/ mbf_2008_06_19_sick.pdf.

27. Cf. note 11 .

\section{References}

Albert, Michel (1993). Capitalism vs. Capitalism: How America's Obsession with Individual Achievement and Short-term Profit has led it to the Brink of Collapse. New York: Four Walls Eight Windows.

Alter, Karen J. (1998). 'Who Are the "Masters of the Treaty"? European Governments and the European Court of Justice', International Organization, 52:1, 121-47.

Alter, Karen J. (2001). Establishing the Supremacy of European Law: The Making of an International Rule of Law in Europe. Oxford: Oxford University Press.

Alter, Karen J., and Sophie Meunier-Aitsahalia (1994). 'Judicial Politics in the European Community. European Integration and the Pathbreaking Cassis de Dijon Decision', Comparative Political Studies, 26:4, 535-61.

Amable, Bruno (2003). The Diversity of Modern Capitalism. Oxford: Oxford University Press. Arnull, Anthony (2003). 'The Community Courts', in M. Cini (ed.), European Union Politics. Oxford: Oxford University Press, 179-91.

Balassa, Bela (1961). 'Towards a Theory of Economic Integration', Kyklos, 14, 1-14.

Burley, Anne-Marie, and Walter Mattli (1993). 'Europe Before the Court: A Political Theory of Legal Integration', International Organization, 47:1, 41-76.

Callaghan, Helen, and Martin Höpner (2005). 'European Integration and the Clash of Capitalisms: Political Cleavages over Takeover Liberalization', Comparative European Politics, 3:3, 307-32.

Dammann, Jens C. (2003). 'The Future of Codetermination after Centros: Will German Corporate Law Move Closer to the U.S. Model?', Fordham Journal of Corporate and Financial Law, VIII:2, 607-81.

Epstein, David, and Sharyn O'Halloran (1999). 'Asymmetric Information, Delegation, and the Structure of Policy-making', Journal of Theoretical Politics, 11:1, 37-56.

European Commission (2005). Flash Eurobarometer Nr. 171: The European Constitution: Post-Referendum Survey in France. Luxembourg: Commission of the European Communities.

Fioretos, Karl-Orfeo (2001). 'The Domestic Sources of Multilateral Preferences: Varieties of Capitalism in the European Community', in Peter Hall and David Soskice (eds.), Varieties of Capitalism. The Institutional Foundations of Comparative Advantage. Oxford: Oxford University Press, 213-44.

Fioretos, Karl-Orfeo (2008). 'The Regulation of International Corporate Identity'. APSA 2008 Annual Meeting, 28 August 2008, Boston, MA.

Franchino, Fabio (2004). 'Delegating Powers in the European Community', British Journal of Political Science, 34:2, 269-93.

Franzese, Robert J. (2002). 'Comparative Institutional and Policy Advantage. The Scope for Divergence within European Economic Integration', European Union Politics, 3:2, 177-203.

Gelter, Martin (2005). 'The Structure of Regulatory Competition in European Corporate Law', Journal of Corporate Law Studies 5:2, 247-84.

Hall, Peter A., and Soskice, David (2001). 'An Introduction to Varieties of Capitalism', in Peter A. Hall and David Soskice (eds.), Varieties of Capitalism. Institutional Foundations of Comparative Advantage. Oxford: Oxford University Press, 1-68.

Héritier, Adrienne (1999). 'The European Polity, Deadlock and Development', in Christian Joerges and Ellen Vos (eds.), EU Committees: Social Regulation, Law and Politics. Oxford/ Portland: Hart Publishing, 273-80.

Hix, Simon, Abdul Noury, and Gerard Roland (2007). Democratic Politics in the European Parliament. Cambridge: Cambridge University Press. 
Hooghe, Liesbet (1999). 'Images of Europe: Orientations to European Integration among Senior Officials of the Commission', British Journal of Political Science, 29:2, 345-67.

Hooghe, Liesbet, and Gary Marks (1999). 'The Making of a Polity: The Struggle over European Integration', in Herbert Kitschelt et al. (eds.), Continuity and Change in Contemporary Capitalism. Cambridge: Cambridge University Press, 70-97.

Höpner, Martin (2007). 'Coordination and Organization: The Two Dimensions of Nonliberal Capitalism', MPIfG Discussion Paper 2007/12. Cologne: Max Planck Institute for the Study of Societies.

Höpner, Martin, and Jackson, Gregory (2006). 'Revisiting the Mannesmann Takeover: How Markets for Corporate Control Emerge', European Management Review, 3:3, 142-55.

Joerges, Christian, and Florian Rödl (2009). 'Informal Politics, Formalised Law and the "Social Deficit" of European Integration: Reflections after the Judgments of the ECJ in "Viking" and "Laval"', European Law Journal, 15:1, 1-19.

Kiewiet, David, and Matthew McCubbins (1991). The Logic of Delegation: Congressional Parties and the Appropriations Process. Chicago: University of Chicago Press.

Maatsch, Sönke (2007). 'The Struggle to Control Meanings: The French Debate on the European Constitution in the Mass Media', Perspectives on European Politics and Society, $8: 3,261-80$.

Majone, Giandomenico (2005). Dilemmas of European Integration. The Ambiguities and Pitfalls of Integration by Stealth. Oxford: Oxford University Press.

McCubbins, Matthew, Roger G. Noll, and Barry R. Weingast (1987). 'Administrative Procedures as Instruments of Political Control', Journal of Law, Economics \& Organization, $3: 2,243-77$.

Menz, Georg (2005). Varieties of Capitalism and Europeanization. National Response Strategies to the Single European Market. Oxford/New York: Oxford University Press.

Milward, Alan S., and Vibeke Sørensen (1994). 'Interdependence or Integration? A National Choice', in Alan S. Milward et al. (eds.), The Frontier of National Sovereignty: History and Theory, 1945-1992. London: Routledge, 1-32.

Moravcsik, Andrew (1998). The Choice for Europe. Social Purpose and State Power from Messina to Maastricht. London: UCL Press.

Moravcsik, Andrew (2002). 'In Defence of the Democratic Deficit: Reassessing Legitimacy in the European Union', Journal of Common Market Studies, 40:4, 603-24.

Pierson, Paul (1996). 'The Path to European Integration: A Historical Institutionalist Analysis', Comparative Political Studies, 29:2, 123-63.

Pollack, Mark A. (2003). The Engines of European Integration. Delegation, Agency, and Agenda Setting in the EU. Oxford: Oxford University Press.

Porter, Michael (1990). The Competitive Advantage of Nations. New York: The Free Press.

Ringe, Niels (2005). 'Policy Preference Formation in Legislative Politics: Structures, Actors, and Focal Points', American Journal of Political Science, 49:4, 731-45.

Roe, Mark J. (2005). 'Delaware's Politics', Harvard Law Review, 118:8, 2491-543.

Scharpf, Fritz W. (1996). 'Negative and Positive Integration in the Political Economy of European Welfare States', in Gary Marks et al. (eds.), Governance in the European Union. London: Sage, 15-39.

Scharpf, Fritz W. (1999). Governing in Europe - Effective and Democratic? New York: Oxford University Press.

Scharpf, Fritz W. (2006). 'The Joint-Decision Trap Revisited', Journal of Common Market Studies, 44:4, 845-64.

Schmidt, Susanne K. (2000). 'Only an Agenda Setter? The European Commission's Power over the Council of Ministers', European Union Politics, 1:1, 37-61.

Schmidt, Susanne K. (2007). 'Introduction: Mutual Recognition as a New Mode of Governance', Journal of European Public Policy, Special Issue on Mutual Recognition as a New Mode of Governance, 14:5, 667-81.

Schmidt, Vivien A. (2002). The Futures of European Capitalism. Oxford: Oxford University Press. 
Shonfield, Andrew (1965). Modern Capitalism. The Changing Balance of Public and Private Power. London/New York/Toronto: Oxford University Press.

Siems, Mathias M. (2002). 'Convergence, Competition, Centros and Conflicts of Law: European Company Law in the 21st Century', European Law Review, 27, 47-59.

Streeck, Wolfgang (1991). 'On the Institutional Conditions of Diversified Quality Production', in Egon Matzner and Wolfgang Streeck (eds.), Beyond Keynesianism: The Socio-economics of Production and Full Employment. Aldershot: Elgar, 21-61.

Streeck, Wolfgang, and Kathleen Thelen (2005). 'Introduction: Institutional Change in Advanced Political Economies', in Wolfgang Streeck and Kathleen Thelen (eds.), Beyond Continuity. Institutional Change in Advanced Political Economies. New York: Oxford University Press, 1-39.

Thatcher, Mark (2007). 'Reforming National Regulatory Institutions: The EU and CrossNational Variety in European Network Industries', in Bob Hancké, Martin Rhodes, and Mark Thatcher (eds.), Beyond Varieties of Capitalism. Conflict, Contradictions, and Complementarities in the European Economy. New York: Oxford University Press, 147-72.

Tsebelis, George, and Geoffrey Garrett (2001). 'The Institutional Foundations of Intergovernmentalism and Supranationalism in the European Union', International Organization, 55:2, 357-90.

Van Apeldoorn, Bastiaan (2000). 'Transnational Class Agency and European Governance: the Case of the European Round Table of Industrialists', New Political Economy, 5:2, 157-81.

Weiler, Joseph H.H. (1991). 'The Transformation of Europe', Yale Law Journal, 100, 2403-83.

Zumbansen, Peer, and Daniel Saam (2007). 'The ECJ, Volkswagen and European Corporate Law: Reshaping the European Varieties of Capitalism', CLPE Research Paper 30/2007. York University: Osgoode Hall Law School. 